\title{
ANALISIS PENGARUH MODEL PEMBELAJARAN PROBLEM SOLVING DAN SIKAP ILMIAH TERHADAP HASIL BELAJAR FISIKA
}

\author{
Sri Purwanti dan Sondang Manurung \\ Jurusan Pendidikan Fisika Pascasarjana Universitas Negeri Medan
}

\begin{abstract}
Abstrak. Penelitian ini bertujuan: Untuk mengetahui apakah ada perbedaan hasil belajar fisika siswa yang diajarkan menggunakan model pembelajaran Problem Solving dengan yang diajarkan menggunakan model pembelajaran Direct Instruction, untuk mengetahui apakah ada perbedaan hasil belajar fisika siswa yang memiliki sikap ilmiah rendah dan sikap ilmiah tinggi, untuk mengetahui apakah ada Interaksi antara model pembelajaran Problem Solving dengan tingkat sikap ilmiah siswa dalam mempengaruhi hasil belajar siswa. Sampel dalam penelitian ini dilakukan secara cluster random sampling sebanyak dua kelas, dimana kelas pertama sebagai kelas eksperimen diterapkan model pembelajaran Problem Solving dan kelas kedua sebagai kelas kontrol diterapkan model pembelajaran Direct Instruction. Instrumen yang digunakan dalam penelitian ini yaitu instrumen tes hasil belajar fisika dalam bentuk uraian sebanyak 8 soal dan insrumen angket sikap ilmiah sebanyak 22 soal yang telah dinyatakan valid dan reliabel. Dari hasil penelitian dapat disimpulkan bahwa terdapat perbedaan hasil belajar fisika siswa dengan model pembelajaran Problem Solving dan model pembelajaran Direct Instruction. Terdapat perbedaan hasil belajar fisika antara sikap ilmiah rendah dan sikap ilmiah tinggi. Terdapat interaksi antara model pembelajaran Problem Solving dengan sikap ilmiah siswa dalam mempengaruhi hasil belajar siswa.
\end{abstract}

Kata kunci: problem solving, sikap ilmiah, hasil belajar

\section{THE ANALYZE EFFECTS OF LEARNING MODEL PROBLEM SOLVING SCIENTIFIC ATTITUDE AND LEARNING OUTCOMES OF PHYSICS}

\author{
Sri Purwanti dan Sondang Manurung \\ Physics Education Program, Graduate State University of medan
}

\begin{abstract}
The purposes of the research are: to determine the differences betwen learning outcomes physics students with problem solving learning model and learning model of Direct Instruction, to determine the difference in results between the studied physics scientific attitude is low and the high, to determine the Interaction between problem solving learning model with the level of scientific attitude of students in influencing student learning outcomes. The sample in this study conducted in cluster random sampling of two classes, where first class as a class experiment applied problem solving learning model and second class as a class of control applied learning model of Direct Instruction. The instruments used in this research
\end{abstract}


achievement test physics in the form of descriptions of 8 questions and insrumen scientific attitude questionnaire with 22 questions that have been declared valid and reliable. From the results of this study concluded that there are differences in learning outcomes physics students with problem solving learning model and model Direct instruction learning. There are differences between the low scientific attitude and high scientific attitude. There is interaction between problem solving learning model with the level of scientific attitude of students in influencing student learning outcomes.

\section{Keywords: problem solving, scientific attitude, learning outcomes}

\section{PENDAHULUAN}

Fisika merupakan ilmu universal yang mendasari perkembangan teknologi modern serta mempunyai peranan penting dalam berbagai disiplin ilmu dan memajukan daya pikir manusia.Pembelajaran fisika memenuhi pengetahuan dasar yang dimiliki semua manusia yaitu membaca, menulis, dan berhitung, siswa diharuskan memiliki kemampuan membaca menulis dan berhitung. Tiga hal itu harus dimiliki siswa karena terkait dengan karakteristik ilmu fisika yang membutuhkan penguasaan konsep, bersifat konstektual, berkembang mengikuti jaman, serta menuntut kemampuan untuk menyelesaikan masalah. Hal yang terjadi jika siswa hanya mempunyai kemampuan membaca dan menulis dalam pembelajaran fisika tanpa di sertai kecakapan berhitung maka siswa tidak akan bisa mengerjakan soal fisika yang kebanyakan adalah soal hitungan.

Proses pembelajaran fisika saat ini berlangsung sebatas pada upaya memberikan pengetahuan deklaratif dalam menggunakan rumus-rumus menyelesaikan soal seperti yang telah dicontohkan sebelumnya. Akibatnya kemampuan siswa dalam pembelajaran fisika hanya terbatas sampai pada kemampuan menghapalkan sekumpulan fakta yang disajikan guru dan tidak mengarah ke pemahaman konsep. Seringkali terjadi kesulitan siswa bila bentuk soal diubah meski masih dalam konsep yang sama yang mengindikasikan siswa tidak memahami makna soal yang sebenarnya. Padahal fisika merupakan ilmu yang lebih banyak memerlukan pemahaman (Siregar,

\section{2).}

Saat ini banyak sekali model pemecahan masalah yang digunakan guru untuk memecahkan kesulitan siswa tersebut diantaranya adalah pembelajaran pemecahan masalah (Arends, 2014). Pembelajaran pemecahan masalah yang dikemukakan oleh John Dewey serta pemecahan masalah yang dikemukakan oleh Jhonsen dan Jhonsen, namun kesemuanya itu memiliki karakteristik dan langkah-langkah yang berbeda. Model yang memiliki karakteristik yang sederhana dan tidak memerlukan waktu banyak, sistematis dan terstruktur, yang sangat sesuai untuk membantu siswa dalam menganalisis soal yang bersifat matematis seperti materi listrik dinamis.

Ketidak aktifan siswa dikarenakan siswa tidak memiliki sikap ilmiah yang baik. Seperti yang kita ketahui, sikap ilmiah memiliki peran tersendiri dalam memotivasi diri siswa aktif dalam melaksanakan pembelajaran sains, karena dengan memiliki sikap ilmiah, siswa akan terdorong untuk menggali lebih jauh untuk menjawab dari rasa ingin tahu yang dimiliki siswa. Sikap ilmiah diartikan sebagai penilaian umum seseorang atas suatu objek yang memiliki tipikal sains atau yang berhubungan dengan sains, disamping itu sikap merupakan fasilitator dan produk dari proses belajar kognitif (Mulyasa, 2007). Sikap Ilmiah dalam proses pembelajaran antara lain sikap ingin tahu, kesabaran, berpikiran terbuka, berpikiran kritis, objektifitas, jujur dan rendah hati, serta peka terhadap lingkungan sekitar.

Kondisi seperti yang diungkapkan di atas 
juga masih terjadi dalam pembelajaran fisika di SMA Muhammadiyah 2 Medan dimana peneliti merupakan guru mata pelajaran fisika di sekolah tersebut. Beberapa temuan peneliti dalam analisis hasil pembelajaran dalam beberapa semester melaksanakan pembelajaran fisika di SMA Muhammadiyah 2 Medan diantaranya, kemampuan siswa untuk menyelesaikan soalsoal yang terkait dengan aktivitas belajar dan kemampuan pemecahan masalah sangat rendah. Rendahnya aktivitas dan kemampuan siswa dalam memanfaatkan sumber belajar untuk menyelesaikan tugas-tugas yang diberikan. Hal ini tergambar dari banyaknya siswa yang tidak sabar dalam menjawab soal, tidak jujur dengan mencontek pekerjaan teman, kurangnya rasa ingin tahu terhadap hal baru dan kurang peka terhadap sekitar.

Beberapa penelitian telah menunjukkan dampak positif dari penerapan Problem Solving dalam pembelajaran. Problem Solving dapat di definisikan lebih luas jika di tinjau dari proses, strategi, keterampilan dan sebagai model pembelajaran. Sebagai suatu proses dalam hal ini terkandung makna ketika siswa belajar ada proses menemukan kembali.

\section{METODE PENELITIAN}

Penelitian ini dilaksanakan pada Semester genap kelas X di SMA Muhammadiyah 2 Medan Tahun Pembelajaran 2014/2015. Populasi dalam penelitian ini adalah siswa di SMA Muhammadiyah 2 Medan Tahun Pembelajaran 2014/2015. Sampel dari penelitian ini adalah siswa kelas X SMA Muhammadiyah 2 Medan dilakukan dengan cara cluster random sampling sebanyak dua kelas, dimana kelas X-1 sebagai kelas eksperimen dengan model pembelajaran Problem Solving dan kelas X-2 sebagai kelas kontrol diterapkan model pembelajaran Direct Instruction.

Variabel penelitian ini terdiri dari3 (tiga) jenis, yaitu variabel bebas, variabel moderatdan variabel terikat. Pada penelitian ini yang menjadi variabel bebas adalah model pembelajaran Problem Solving, Variabel moderat adalah sikap ilmiah sedangkan variabel terikat pada penelitian ini adalah hasil belajar.

Penelitian ini menggunakan quasi eksperimen (eksperimen semu). Menurut Suryabrata (2008) bahwa tujuan eksperimen semu untuk memperoleh informasi yang merupakan perkiraan bagi informasi yang dapat diperoleh dengan eksperimen yang sebenarnya dalam keadaan yang tidak memungkinkan untuk mengontrol semua variabel yang relevan.

Desain penelitian ini berupa Two Group Pretest-Postes Design. Penelitian ini melibatkan dua kelas yaitu kelas kontrol dan kelas eksperimen yang diberi perlakukan berbeda. Pada kelas eksperimen diberi perlakuan model pembelajaran Problem Solving dan pada kelas kontrol diberi perlakuan pembelajaran Direct Instruction. Adapun desain penelitian untuk ANAVA 2 x2 ditunjukkan pada Tabel 1.

Tabel 1. Desain Penelitian ANAVA

\begin{tabular}{|c|c|c|}
\hline \multirow[b]{2}{*}{$\begin{array}{l}\text { Sikap } \\
\text { Ilmiah } \\
\text { (B) }\end{array}$} & \multicolumn{2}{|c|}{ Hasil Belajar (B) } \\
\hline & $\begin{array}{c}\text { Direct } \\
\text { Instruction } \\
\left(\mathrm{A}_{1}\right)\end{array}$ & $\begin{array}{c}\text { Problem } \\
\text { Solving } \\
\left(\mathrm{A}_{2}\right)\end{array}$ \\
\hline Tinggi $\left(B_{1}\right)$ & $\mathrm{A}_{1} \mathrm{~B}_{1}$ & $\mathrm{~A}_{2} \mathrm{~B}_{1}$ \\
\hline Rendah $\left(B_{2}\right)$ & $\mathrm{A}_{1} \mathrm{~B}_{2}$ & $\mathrm{~A}_{2} \mathrm{~B}_{2}$ \\
\hline & $\mu \mathrm{A}_{1}$ & $\mu \mathrm{A}_{2}$ \\
\hline
\end{tabular}

Untuk menguji hipotesis penelitian digunakan teknik analisa data dengan analisis varian (ANAVA) dua jalur (desain faktorial $2 \times 2$ ) dengan taraf signifikan $\alpha=0,05$ atau $5 \%$.

\section{HASIL PENELITIAN DAN PEMBAHASAN Hasil Penelitian}

Deskripsi data yang disajikan dalam hasil penelitian ini terdiri dari hasil belajar dan sikap ilmiah siswa dengan menggunakan model pembelajaran Problem Solving pada kelas eksperimen memperoleh nilai rata-rata sebesar 76,90 dan model pembelajaran Direct Instruction pada kelas kontrol memperoleh nilai rata-rata sebesar 73,49. Pengujian dilakukan dengan menggunakan SPSS 16.0 dengan uji ANAVA dua jalur. Maka kedua data tersebut diuji 
homogenitasnya terlebih dahulu. Uji normalitas belajar ditunjukkan pada Tabel 2 .

Tabel 2. Uji Normalitas Hasil Belajar Antar Kelompok

\begin{tabular}{crrr}
$F$ & df1 & df2 & Sig. \\
\hline 0.578 & 3 & 74 & 0.631 \\
\hline
\end{tabular}

Hasil pengujian yang terdapat pada Tabel 2. memperlihatkan nilai $\mathrm{F}$ untuk hasil belajar 0,578 dengan signifikansi 0.631. Berdasarkan hasil tersebut signifikan hitung lebih besar dibandingkan signifikan 0.05 sehingga dapat disimpulkan data pretes hasil belajar antar kelompok memiliki varians yang sama.

Output ANAVA dari penelitian dapat dilihat pada tabel 3 .

Tabel 3. Output perhitungan ANAVA Dua Jalur

\begin{tabular}{|c|c|c|c|c|c|}
\hline Source & $\begin{array}{l}\text { Type III } \\
\text { Sum of } \\
\text { Squares }\end{array}$ & df & $\begin{array}{c}\text { Mean } \\
\text { Square }\end{array}$ & $\mathrm{F}$ & Sig. \\
\hline Model & 216.616 & 1 & 216.616 & 10.321 & 0.002 \\
\hline SikapIlmiah & 188.2 & 1 & 188.2 & 8.967 & 0.004 \\
\hline $\begin{array}{l}\text { Model * } \\
\text { SikapIlmiah }\end{array}$ & 674.367 & 1 & 674.367 & 32.133 & 0.001 \\
\hline
\end{tabular}

Berdasarkan Tabel 3. perhitungan Anava pada signifikan model diperoleh hasil signifikan 0,002 dan signifikan ini lebih kecil dibandingkan signifikan $\alpha=0,05$. Maka terdapat perbedaan yang signifikan hasil belajar siswa yang diajarkan melalui model Problem Solving dan model Direct Instruction. Pada signifikan sikap ilmiah diperoleh hasil 0,004 dan signifikan ini lebih kecil dibandingkan signifikan $\alpha=0,05$. Maka terdapat perbedaan hasil belajar antara siswa yang memiliki sikap ilmiah tinggi dan sikap ilmiah rendah. Pada signifikan model*sikap ilmiah yaitu 0.001 dan signifikan ini lebih kecil dibandingkan signifikan $\alpha=0,05$. Terdapat interaksi antara model pembelajaran dengan sikap ilmiah siswa untuk meningkatkan hasil belajar fisika siswa. Hal ini dapat terlihat jelas pada Gambar 1.
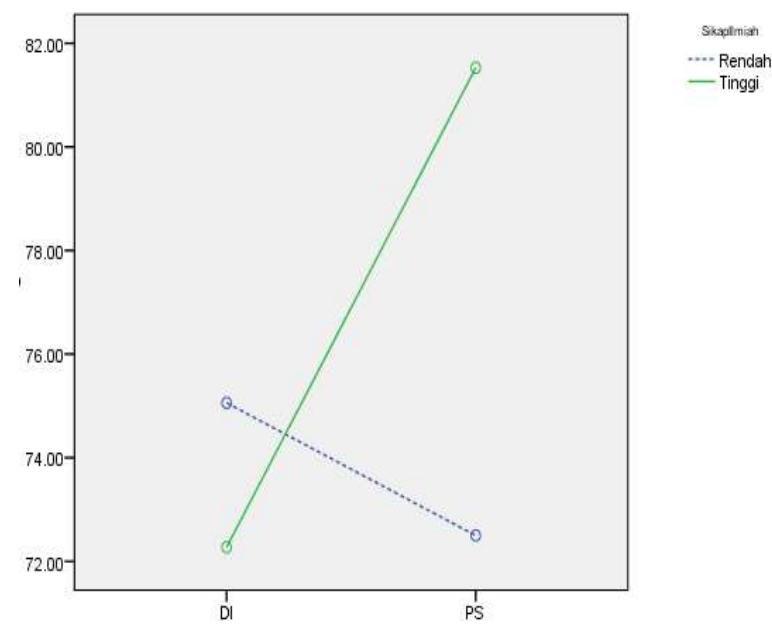

Gambar 1. Interaksi Model Pembelajaran dan Sikap Ilmiah

Dari Gambar 1. terlihat grafik hubungan antara model pembelajaran dan hasil belajar pada sikap ilmiah tinggi dan rendah. Terdapat interaksi yang signifikan antara model pembelajaran dan sikap ilmiah dalam mempengaruhi hasil belajar siswa.

\section{Pembahasan}

Belajar sebagai perubahan tingkah laku pada diri individu berkat adanya interaksi antara individu dengan individu dan individu dengan lingkungannya sehingga siswa mampu berinteraksi dengan lingkungannya. Dalam buku Educational Psychology, oleh Witherington, mengemukakan bahwa belajar adalah suatu perubahan di dalam kepribadian yang menyatakan diri sebagai suatu pola baru dari reaksi berupa kecakapan, sikap, kebiasaan atau suatu pengertian. (Aunurrahman, 2009).

Banyak permasalahan yang ditemui pada pembelajaran fisika, permasalahan tersebut muncul tidak hanya dari diri siswa sendiri, melainkan dari cara dan metode guru juga sangat menentukan keberhasilan dari proses pembelajaran fisika. Menyikapi permasalahan yang timbul dalam proses pembelajaran fisika di sekolah, terutama yang berkaitan dengan pentingnya pemecahan masalah yang akhirnya mengakibatkan rendahhnya hasil belajar.

Salah satu solusi untuk mengurangi permasalahan di atas dengan menerapkan 
model Problem Solving dalam pembelajaran, karena pembelajaran fisika akan lebih bermakna dan menarik bagi siswa jika guru menghadirkan masalah-masalah kontekstual dan realistik, yaitu masalah-masalah yang sudah dikenal, dekat dengan kehidupan riil sehari-hari dimana ketika siswa dihadapkan dengan situasi masalah siswa dapat melakukan keterampilan memecahkan masalah untuk memilih dan mengembangkan tanggapan, tidak hanya dengan cara menghapal tanpa berpikir, keterampilan memecahkan masalah memperluas proses berpikir, dan hal tersebut merupakan karakteristik dari Problem Solving.

Tidak hanya dengan cara menghafal tanpa, ketrampilan memecahkan masalah memperluas proses berfikir. Dalam Problem Solving terdapat dua proses kreatif dalam pemecahan masalah yaitu fase imaginative dan fase praktis. Dalam fase imaginative gagasan strategi pemecahan masalah diperoleh, dan dalam fase praktis, gagasan tersebut dievaluasi dan dilaksanakan. Dalam fase divergen dilakukan sumbang saran (brainstorming) untuk memperkaya gagasan dan ide pemecahan masalah. Fase konvergen yang merupakan proses pemikiran logis diperlukan untuk menganalisis secara kritis gagasan atau ide yang paling bermutu, tepat dan relevan.

Pembelajaran Problem Solving siswa diberi kesempatan untuk melakukan kegiatan, siswa merasa nyaman saat pelakukan pembelajaran, siswa aktif bertanya akan apa yang mereka kurang pahami saat melakukan pembelajaran. Siswa menjadi aktif dalam meningkatkan hasil belajar siswa. Dalam proses memecahkan masalah, siswa dituntut aktif melakukan serangkaian percobaan seperti hukum Ohm, rangkaian seri-paralel dan hukum kirchov I. Dari kegiatan tersebut siswa melakukan pengamatan dan pengukuran besaran listrik seperti tegangan dan kuat arus. Data yang diperoleh kemudian dirangkai dalam suatu konsep fisika tentang listrik dinamis. Proses tanya-jawab antarsiswa dan guru juga berlangsung dengan baik sehingga tingkat pemahaman akan konsep fisika juga akan lebih baik. Jadi tepat kiranya siswa yang diajarkan dengan model Problem Solving mendapat hasil belajar yang baik.

Sikap ilmiah adalah sikap yang melekat dalam diri seseorang setelah mempelajari sains, kondisi seseorang dalam merespon, menanggapi, dan berprilaku berdasarkan ilmu pengetahuan dan etika ilmiah yang telah diakui kebenarannya. Rasa ingin tahu, rasional, pengambilan keputusan, berpikir terbuka, kritis, objektif, jujur dan rendah hati menjadi warna dalam seseorang bersikap.

Seseorang dengan sikap ilmiah yang tinggi mampu berpikir dengan logis selama melakukan pembelajaran, dengan pemikiran terbuka ia mampu menerima pendapat orang lain, mengatakan apa yang sebenarnya, menyimpulkan sesuatu dengan pertimbangan sebabakibat, objektif. Hal ini juga terlihat selama penelitian, siswa aktif dalam pembelajaran melakukan percobaan dengan serius. Dialog antar anggota kelompok terjadi dengan baik proses diskusi berlangsung dengan saling menghargai pendapat satu sama lain. Hasil percobaan disajikan seperti apa yang diperoleh selama percobaan. Penarikan kesimpulan juga berlangsung dalam proses yang baik dengan mempertimbangkan seluruh data dan konsep fisika tentang rangkaian listrik.

Berbeda dengan siswa yang kesulitan mengikuti pembelajaran aktif yang umumnya memiliki Sikap Ilmiah yang rendah. Suasana kelas cenderung ribut, siswa tidak mengetahui apa yang harus ia lakukan. Saat melakukan percobaan siswa menunggu perintah kerja dari guru, kurangnya rasa tanggung jawab menyebabkan siswa terkesan tidak peduli dengan pembelajarannya. Diskusi berlangsung pasif karena hanya berpusat pada seseorang yang dianggap mampu sajalah yang mengambil keputusan dalam kelompok.

Siswa yang memiliki sikap ilmiah tinggi lebih mudah menerima pembelajaran aktif, sikap ilmiah siswa terfasilitasi dengan aktivitasaktivitas percobaan yang menggugah rasa ingain tahu siswa. Siswa merancang alat, melakukan percobaan, mengamati jalannya 
percobaan menunjukan bahwa siswa beratinggung jawab atas tugas-tugas yang diberikan. Siswa bersikap jujur dalam menuliskan data hasil perconbaan. Saat mendiskusikan hasil percobaan dan menyimpulkan konsep Fisika yang mereka temukan sikap keterbukaan dan menghargai orang lain memegang perananan penting. Semua runtutan proses tersebut membuat siswa mampu memecahkan permasalahan dalam pembelajaran sehingga Hasil belajar siswa meningkat.

Siswa yang memiliki Sikap Ilmiah rendah saat diajarkan dengan Model Pembelajaran Problem Solving mengalami kesulitan saat belajar. Mereka sering diam didalam kelompoknya, melihat teman-temannya yang lain bekerja melakukan percobaan. Tidak jarang ditemukan siswa hanya menulis atau menggambar yang tidak berhubungan dengan percobaan. Dalam berdiskusi siswa juga kesulitan memberi ide, saran ataupun masukan pada kelompok, mereka cenderung diam dan mengikuti apa yang menjadi kesimpulan dari teman sekelompoknya yang aktif melakukan percobaan. Selama proses presentase hasil percobaan siswa dengan Sikap Ilmiah rendah ini juga mengambil posisi pasif dan tidak menjawab pertanyaan yang diajukan dari kelompok lain. Jadi wajar kiranya hasil belajar mereka rendah.

Berbeda dengan siswa yang diajarkan dengan Model Pembelajaran Direct Instruction, model ini melibatkan siswa pada latihan langsung, dimana guru mengambil peranan penting sebagai sumber pembelajaran. Siswa yang memiliki Sikap Ilmiah tidak begitu tepat diajarkan dengan model ini. Siswa dengan Sikap Ilmiah tinggi tidak mendapat kesempatan untuk mengaktualisasikan pemikiran mereka seperti berpendapat dan mencoba menemukan sendiri pengetahuannya selama belajar, sehingga hasil belajarnya pun rendah.

Siswa dengan Sikap Ilmiah rendah mendapat kesempatan untuk mendapatkan penjelasan yang cukup tentang materi pembelajaran. Namun dalam penguasaan Hasil belajar siswa dengan Sikap Ilmiah rendah juga mengalami kesulitan untuk melakukan pembelajaran. Pengalaman belajar yang dialami siswa di kelas dengan Model Pembelajaran Direct Instruction sama dengan Model Pembelajaran Problem Solving. Siswa sulit mengikuti aktivitas-aktivitas sains, siswa cenderung mencari kesibukan lain seperti menulis, menggambar, mengobrol dengang teman bahkan ada yang hanya terdiam. Sehingga Hasil belajar siswa juga tidak terlalu baik.

\section{DAFTAR PUSTAKA}

Arends, R.I. 2004. Lerning To Teach. New York, NY 10020: McGraw-Hill Commpanies, Inc.

Aunurrahman. 2009. Belajar dan Pembelajaran. Bandung: Alfabeta.

Mulyasa. 2007. Menjadi Guru Profesional Menciptakan Pembelajaran Kreatif dan Menyenangkan. Bandung: Remaja Rosda Karya.

Siregar, H. 2012. Pengaruh Pembelajaran Kooperatif (Tipe STAD, Tipe NHT) dan Motivasi Belajar Terhadap Hasil Belajar Biologi dan Kemampuan Berpikir Kritis Siswa M.Ts Negeri 3 Medan, Tesis, Program Pascasarjana, Unimed, Medan.

Suryabrata, S. 2008. Metodologi Penelitian. Jakarta: PT. Raja Grafindo Persada. 